\title{
Microbial community dynamics in an ANAMMOX reactor for piggery wastewater treatment with startup, raising nitrogen load, and stable performance
}

\author{
Qiang Huang ${ }^{1,2}$, Wei-Li Du ${ }^{1,2}$, Li-Li Miao $^{1}$, Ying Liu ${ }^{1}$ and Zhi-Pei Liü ${ }^{*}$
}

\begin{abstract}
Bacterial community dynamics of the ANAMMOX reactor of an integrated "UASB + SHARON + ANAMMOX" system for treating piggery wastewater were investigated using the Illumina MiSeq method with samples obtained at 2-week intervals during a 314-day period. With aerobic activated sludge as seeds and low content artificial wastewater $\left(\mathrm{NH}_{4}{ }^{+}-\mathrm{N} 50 \mathrm{mg} / \mathrm{L} ; \mathrm{NO}_{2}{ }^{-}-\mathrm{N} 55 \mathrm{mg} / \mathrm{L}\right)$ as influent for the ANAMMOX reactor, nitrogen removal was initially observed on day 38 with a removal rate $1.3 \mathrm{mg} \mathrm{N} \mathrm{L}^{-1}$ day ${ }^{-1}$, and increased to $90.4 \mathrm{mg} \mathrm{N} \mathrm{L}^{-1}$ day ${ }^{-1}$ on day 55 with almost complete removal of ammonia and nitrite, indicating a successful startup of the reactor. Increasing influent load stepwise to $\mathrm{NH}_{4}{ }^{+}-\mathrm{N} 272.7 \mathrm{mg} / \mathrm{L} \mathrm{NO}_{2}{ }^{-}-\mathrm{N} 300 \mathrm{mg} / \mathrm{L}$, nitrogen removal rate increased gradually to $470 \mathrm{mg} \mathrm{N} \mathrm{L}^{-1}$ day ${ }^{-1}$ on day 228 , and maintained a stable level $\left(\sim 420 \mathrm{mg} \mathrm{N} \mathrm{L}^{-1}\right.$ day $\left.{ }^{-1}\right)$ following introduction of SHARON effluent since day 229. Correlation between microbial community dynamics and nitrogen removal capability was significant $(r=0.489$, $p<0.001)$. Microbial community composition was determined by influent ammonia, influent nitrite, effluent nitrate and some undefined factors. Anammox bacteria, accounting for $~ 98.7 \%$ of Planctomycetes, became detectable ( $0.03 \%$ relative abundance) since day 38 and increased to $0.9 \%$ on day 58 , well consistent with nitrogen removal performance of the reactor. Relative abundance of anammox bacteria gradually increased to $38.4 \%$ on day 140 with stepwise increased influent load; decreased to $0.4 \%$ on day 169 because of nitrite inhibition; increased to $19.24 \%$ on day 233 when the influent load was dropped; kept at $~ 9.0 \%$ with SHARON effluent used as influent and dropped to 3.3\% finally. Anammox bacteria, only Candidatus Brocadia and Ca. Kuenenia detected, were the most abundant at genus level. Ca. Brocadia related taxa were enriched firstly under low load and detectable during the entire experimental period. Three main groups represented by $\mathrm{Ca}$. Brocadia related OTUs were enriched or eliminated at different loads, but Ca. Kuenenia related taxa were enriched only under high load $\left(\mathrm{NO}_{2}{ }^{-}-\mathrm{N}>300 \mathrm{mg} / \mathrm{L}\right)$, suggesting their different niches and application for different loads. These findings improve the understanding of relationships among microbial community/functional taxa, running parameters and reactor performance, and will be useful in optimizing running parameters for rapid startup and high, stable efficiency.
\end{abstract}

Keywords: ANAMMOX, Anammox bacteria, Microbial community dynamics, Stepwise increasing load, Piggery wastewater

\footnotetext{
*Correspondence: liuzhp@im.ac.cn

1 State Key Laboratory of Microbial Resources, Institute of Microbiology,

Chinese Academy of Sciences, No. 1 West Beichen Road, Chaoyang

District, Beijing 100101, People's Republic of China

Full list of author information is available at the end of the article
} 


\section{Introduction}

Ammonia pollution from pig farm has steadily increased worldwide in recent decades and presents serious environmental problems (Ali et al. 2013). Ammonia and chemical oxygen demand (COD) are the two main and high content pollutants in piggery wastewater (Bernet et al. 2000; Zhu et al. 2013). Anaerobic digestion methods, e.g., upflow anaerobic sludge bed (UASB) reactor, have been widely used to eliminate COD coupled with biogas production (Hashimoto 1983). Conventional nitrification-denitrification methods require large amount of energy and organic materials, resulting in high operational cost and limited application (Bernet et al. 1996; Boiran et al. 1996).

The anaerobic ammonium oxidation process (ANAMMOX), a more recently developed approach for nitrogen removal from wastewater, has the advantages of high efficiency, low sludge production, and no organic material requirement (Strous et al. 1999). Application of ANAMMOX for treatment of ammonia-rich wastewater reduced operational costs by $\sim 90 \%$ (Jetten et al. 2001). Anammox bacteria, members of Planctomycetes, oxidize ammonia with nitrite as electron acceptor to produce dinitrogen gas $\left(\mathrm{N}_{2}\right)$ (Strous et al. 1999; van de Graaf et al. 1995). In order to satisfy ANAMMOX reactor, a half partial nitrification process, e.g. a single reactor for high activity ammonium removal over nitrite (SHARON), was necessary to convert $50 \%$ of ammonia to nitrite. Combined process SHARON-ANAMMOX had been applied for piggery wastewater treatment, but the nitrogen removal efficiency was not ideal due to high organic content, which would seriously inhibite anammox bacteria (Hwang et al. 2005; Jin et al. 2012; Tang et al. 2010; Yamamoto et al. 2008).

In addition to anammox bacteria, heterotrophic bacteria, e.g. Proteobacteria, Chloroflexi, Chlorobi, Bacteroidetes, and Acidobacteria, also played important roles in ANAMMOX bioreactor (Chen et al. 2017; Hwang et al. 2005; Lawson et al. 2017; Suto et al. 2017). Microbial community compositions in a bioreactor directly determined the reactor efficiency (Cho et al. 2010; Finlay et al. 1997), and would shift to adapt to those environmental changes, including organic materials, substrates (nitrite, ammonia), salinity, and running parameters [dissolved oxygen (DO), pH, temperature] (Egli et al. 2001; Isaka et al. 2007; Jin et al. 2012). Most studies to date have investigated the microbial communities in ANAMMOX reactors, especially for piggery wastewater treatment (Chen et al. 2017; Hwang et al. 2005; Suto et al. 2017). However, those studies focused on microbial communities at a single time point, this did not permit evaluation of microbial community dynamics, mutual interactions among anammox bacteria and other microorganisms, or effects of environmental factors on microbial communities in reactors. Evaluation of microbial community changes in relation to environmental factors reveals relationships between community dynamics and microecosystem functions (Finlay et al. 1997), and is useful for achieving quick startup, running parameter optimization, and stably efficient maintenance of ANAMMOX reactors. It is highly desirable to examine microbial community dynamics over the entire running period, in order to observe relationships among these dynamics, reactor performance, and environmental factors.

We recently constructed an integrated system termed "UASB + SHARON + ANAMMOX" for treating piggery wastewater. Performance of a laboratory-scale system was stable and efficient (MS submitted). In the present study, we used the Illumina MiSeq method to investigate microbial community dynamics of the ANAMMOX reactor of this integrated system with samples obtained at $\sim 2$-week intervals during a 314-day period. Correlations were examined between community dynamics and nitrogen removal efficiency during startup, acclimation period, introduction of SHARON effluent and stable/ efficient treatment period. Environmental factors affecting the community dynamics were evaluated. Changes of anammox bacterial compositions were also elucidated during the entire running time. Our findings will be useful in comprehension of relationships among microbial community composition, nitrogen removal efficiency and running parameters, and help optimizing running parameters for rapid startup and stable performance of ANAMMOX reactors in practical application.

\section{Materials and methods}

\section{ANAMMOX reactor and running parameters}

A laboratory-scale "UASB + SHARON + ANAMMOX" system (Additional file 1: Fig. S1; Table S1) was constructed for experimental treatment of piggery wastewater (COD 5500-8500 mg/L/ $\mathrm{NH}_{4}{ }^{+}-\mathrm{N} 500-1500 \mathrm{mg} / \mathrm{L}$ ) obtained from an animal husbandry facility in Changping District, Beijing, China. The three reactors of the system were started up separately, and integrated on day 229. The purpose of the third reactor (ANAMMOX) was to remove nitrogen compounds (mainly ammonia and nitrite) present in effluent from the second reactor (SHARON). The ANAMMOX reactor was constructed of plexiglass [poly(methyl methacrylate)] with height $1400 \mathrm{~mm}$, diameter $140 \mathrm{~mm}$, and effective volume 13.3 L. Activated sludge obtained from the aeration tank of a wastewater treatment plant was used as inoculum, with filling ratio $30 \%(\mathrm{v} / \mathrm{v})$ for startup. Concentrations of volatile solids (VS) and suspended solids (SS) in seed sludge were 3500 and $4870 \mathrm{mg} / \mathrm{L}$, respectively. ANAMMOX temperature was maintained at $31-32{ }^{\circ} \mathrm{C}$ 
by a water jacket, with hydraulic retention time (HRT) $26.6 \mathrm{~h}$. The reaction was started up with artificial wastewater $\left(\mathrm{NH}_{4} \mathrm{Cl}, \mathrm{NaNO}_{2}, \mathrm{NaHCO}_{3}\right.$, and $\mathrm{Na}_{2} \mathrm{HPO}_{4} \cdot 12 \mathrm{H}_{2} \mathrm{O}$; $7: 10: 2: 2 \mathrm{w} / \mathrm{w})$ having initially low nitrogen load $\left(\mathrm{NH}_{4}{ }^{+}-\mathrm{N}\right.$ $50 \mathrm{mg} / \mathrm{L} / \mathrm{NO}_{2}{ }^{-}-\mathrm{N} 55 \mathrm{mg} / \mathrm{L}$ ), and increasing gradually to $\mathrm{NH}_{4}{ }^{+}-\mathrm{N} 300 \mathrm{mg} / \mathrm{L} / \mathrm{NO}_{2}{ }^{-}{ }^{-} \mathrm{N} 330 \mathrm{mg} / \mathrm{L}$. On day 229, artificial wastewater was replaced by SHARON effluent. DO and $\mathrm{pH}$ were not controlled.

\section{Sludge samples and DNA extraction}

Sludge samples (21 in total) were collected from the bottom (activated sludge assembled at the bottom of bioreactor) of the ANAMMOX reactor at $\sim 2$-week intervals during the entire running period (314 days). Six SHARON reactor samples [obtained during days 220-290 in aeration status (Du et al. 2016)] were used as references.

Total genomic DNA was extracted from each sample ( $\sim 0.5$ g) using a PowerSoil DNA isolation kit (MO BIO Laboratories; Shenzhen, China) as per the manufacturer's instructions, and stored at $-80^{\circ} \mathrm{C}$.

\section{Illumina MiSeq sequencing analysis of 16S rRNA gene amplicons}

Bacterial communities of the 21 ANAMMOX samples and six SHARON samples were analyzed. The V3-V4 hypervariable region of bacterial $16 \mathrm{~S}$ rRNA gene was amplified using primer set 338F/806R, and 468-bp fragments were obtained and subjected to sequencing/ analysis on the Illumina MiSeq PE300 platform. Raw data were processed using the Quantitative Insights Into Microbial Ecology (QIIME v. 1.8.0) toolkit (Caporaso et al. 2010). Chimeric sequences were checked and filtered using UCHIME (Edgar et al. 2011). Quality reads were clustered into operational taxonomic units (OTUs) with $97 \%$ sequence similarity cutoff using UPARSE (Edgar \& Robert, 2013). Representative sequence of each OTU was selected for taxonomic assignment using the Greengenes database, v. 13-8 (Wang et al. 2007). For all OTU-based analyses, sequence number was normalized prior to statistical analysis to the smallest sample size. QIIME was used to create Bray-Curtis distance metrics and $\alpha$-diversity indexes, including $\mathrm{ACE}$, Chao 1 richness estimation, Shannon, Simpson, and Good's coverage. The analyzed sequences were deposited in Sequence Read Archive (SRA) database under accession number SRP108925.

\section{Analytical methods}

$\mathrm{NH}_{4}{ }^{+}-\mathrm{N}, \mathrm{NO}_{2}{ }^{-}-\mathrm{N}$, and $\mathrm{NO}_{3}{ }^{-}-\mathrm{N}$ were determined using a water quality analyzer (Aquakem 600, Thermo Fisher Scientific). DO was measured with a DO meter (model JPSJ-605; Shanghai Precision \& Scientific Instrument
Co.; Shanghai, China). $\mathrm{pH}$ was measured with a $\mathrm{pH}$ meter (model PB-10; Sartorius; Germany).

\section{Statistical analysis}

Patterns of microbial community dynamics in the ANAMMOX reactor during the entire running period were evaluated by Principal Coordinates Analysis (PCoA) based on Bray-Curtis distance (Gauch and Hugh 1973). Correlations between community dynamics and environmental factors were evaluated by redundancy analysis (RDA). The contribution of environmental factors in driving community dynamics was assessed using variation partitioning analysis (VPA). Correlations between community dynamics and nitrogen removal capacity were assessed by Mantel test. Pearson's test was used to evaluate correlations between environmental factors and major phyla, and $\alpha$-diversities. The above analyses were performed using the R software program (v. 3.2.1; http:// www.r-project.org). Phylogenetic trees were constructed using the MEGA 6.0 software program (Tamura et al. 2013), based on representative sequence for each OTU, by neighbor-joining $(\mathrm{NJ})$ method with bootstrap values calculated from 1000 replications.

\section{Results}

\section{Performance of ANAMMOX reactor}

Low influent load $\left(\mathrm{NH}_{4}{ }^{+}-\mathrm{N} 50 \mathrm{mg} / \mathrm{L} / \mathrm{NO}_{2}{ }^{-}-\mathrm{N} 55 \mathrm{mg} / \mathrm{L}\right)$ was used for startup of ANAMMOX reactor. Effluent ammonia and nitrite levels showed no significant decrease through day 1 to day 37, then nitrogen removal was initially observed since day 38 with a removal rate of $1.3 \mathrm{mg} \mathrm{N} \mathrm{L}{ }^{-1} \mathrm{day}^{-1}$. Effluent ammonia and nitrite level dropped rapidly to undetectable level by day 55 , and nitrogen removal rate reached to $90.4 \mathrm{mg} \mathrm{N}$ $\mathrm{L}^{-1} \mathrm{day}^{-1}$ (Fig. 1), indicating the successful startup. After day 59, influent load was increased gradually to $\mathrm{NH}_{4}{ }^{+}-\mathrm{N} 200 \mathrm{mg} / \mathrm{L} / \mathrm{NO}_{2}{ }^{-}-\mathrm{N} 220 \mathrm{mg} / \mathrm{L}$ by day 120 , during which time nitrate increased gradually to $\sim 50 \mathrm{mg} / \mathrm{L}$ $\mathrm{NO}_{3}{ }^{-}-\mathrm{N}$ but no ammonia or nitrite was present in effluent (Fig. 1). Influent load was then increased gradually to $\mathrm{NH}_{4}{ }^{+}-\mathrm{N} 272.7 \mathrm{mg} / \mathrm{L} / \mathrm{NO}_{2}{ }^{-}-\mathrm{N} 300 \mathrm{mg} / \mathrm{L}$ from day 130 to 160 , with accompanying increases in effluent to $\mathrm{NH}_{4}{ }^{+}-\mathrm{N} \sim 60 \mathrm{mg} / \mathrm{L}, \mathrm{NO}_{2}{ }^{-}-\mathrm{N} \sim 40 \mathrm{mg} / \mathrm{L}$, and $\mathrm{NO}_{3}{ }^{-}-\mathrm{N} \sim 60 \mathrm{mg} / \mathrm{L}$. From day 161 to 187 , influent load was increased to $\mathrm{NH}_{4}{ }^{+}-\mathrm{N} 300 \mathrm{mg} / \mathrm{L} / \mathrm{NO}_{2}{ }^{-}-\mathrm{N} 330 \mathrm{mg} / \mathrm{L}$, accompanied by increase of $\mathrm{NH}_{4}{ }^{+}-\mathrm{N}$ in effluent to $\sim 80 \mathrm{mg} / \mathrm{L}$, but no notable increase of nitrite or nitrate. Nitrogen removal efficiency improved when the influent load decreased to $\mathrm{NH}_{4}{ }^{+}-\mathrm{N} 272.7 \mathrm{mg} / \mathrm{L}$ and $\mathrm{NO}_{2}{ }^{-}-\mathrm{N}$ $300 \mathrm{mg} / \mathrm{L}$. Stepwise increasing influent load, total nitrogen removal rate increased gradually to $470 \mathrm{mg} \mathrm{N}$ $\mathrm{L}^{-1}$ day $^{-1}$ at day 228, and was maintained at this level thereafter, despite the reduction in efficiency at high load. 


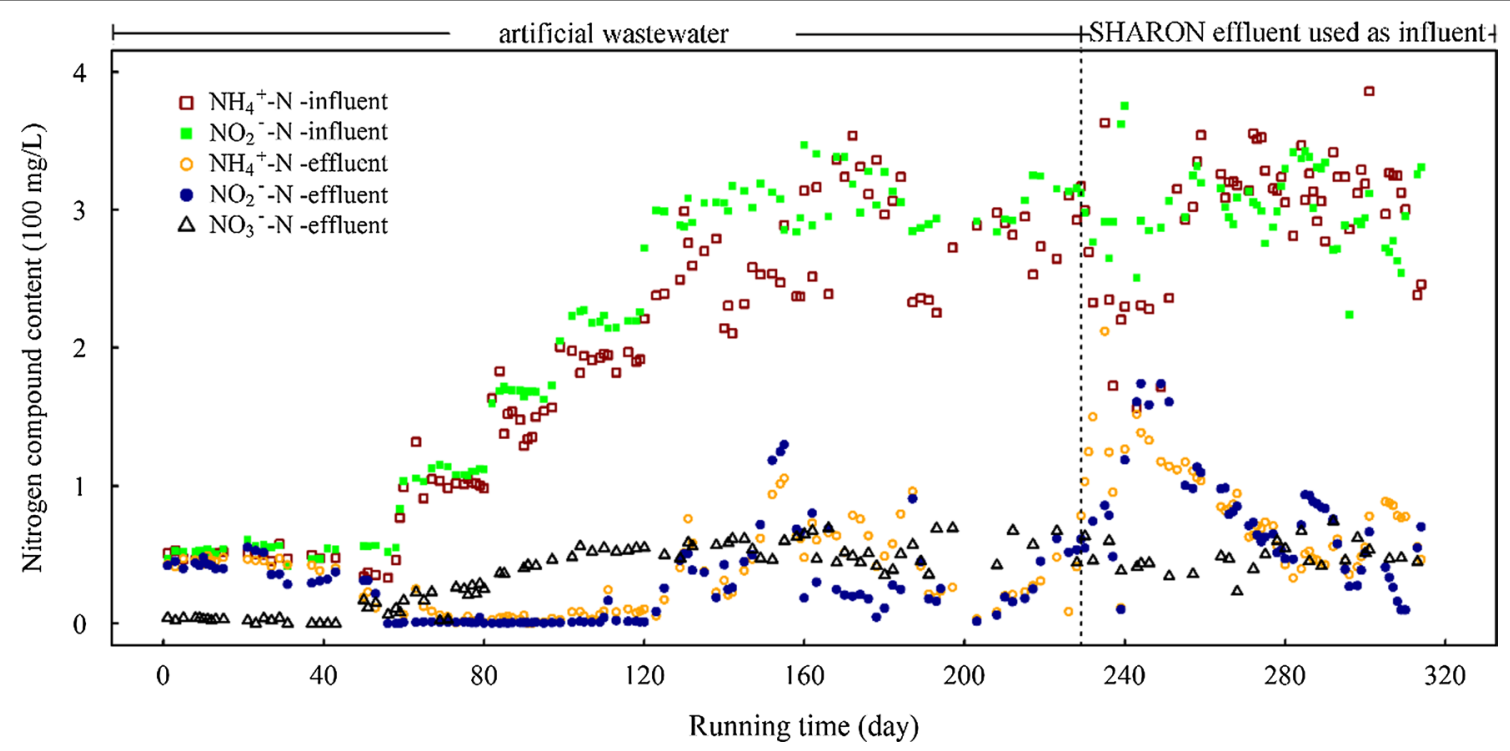

Fig. 1 Performance of ANAMMOX reactor during entire running time. Dotted line: day 229, when SHARON effluent was introduced as ANAMMOX influent

SHARON effluent (piggery wastewater following anaerobic digestion and partial nitrification; $\mathrm{NH}_{4}{ }^{+}-\mathrm{N}$ $297.54 \pm 48.96 \mathrm{mg} / \mathrm{L}, \mathrm{NO}_{2}{ }^{-}-\mathrm{N} \quad 301.69 \pm 28.51 \mathrm{mg} / \mathrm{L}$, $\mathrm{NO}_{3}{ }^{-}-\mathrm{N} \quad 3.32 \pm 1.44 \mathrm{mg} / \mathrm{L}$ ) was used as ANAMMOX influent on day 229. Effluent nitrogen levels increased rapidly to $\mathrm{NH}_{4}{ }^{+}-\mathrm{N} \sim 163.6 \mathrm{mg} / \mathrm{L} /$ $\mathrm{NO}_{2}{ }^{-}-\mathrm{N} \sim 186.4 \mathrm{mg} / \mathrm{L} / \mathrm{NO}_{3}{ }^{-}-\mathrm{N} \sim 60 \mathrm{mg} / \mathrm{L}$ (Fig. 1). Total nitrogen removal rate declined to $212 \mathrm{mg} \mathrm{N} \mathrm{L}^{-1}$ day $^{-1}$ by day 233 . After $\sim 1$ month acclimation, effluent nitrogen decreased gradually and was then steadily maintained at $\mathrm{NH}_{4}{ }^{+}-\mathrm{N} \sim 42.8 \mathrm{mg} / \mathrm{L} / \mathrm{NO}_{2}{ }^{-}-\mathrm{N} \sim 52.4 \mathrm{mg} / \mathrm{L} /$ $\mathrm{NO}_{3}{ }^{-}-\mathrm{N} \sim 57.2 \mathrm{mg} / \mathrm{L}$, with nitrogen removal rate maintained at $\sim 420 \mathrm{mg} \mathrm{N} \mathrm{L}^{-1}$ day $^{-1}$ (Fig. 1).

\section{Illumina MiSeq sequencing results, and community structure/dynamics}

For the 27 total samples (21 ANAMMOX, 6 SHARON), 974,987 high-quality sequences in total were obtained from 1163,298 sequences of raw data after sequence processing. Number of sequences of individual samples ranged from 25,958 (SBR-220) to 46,740 (AN-109). Sequences for all samples were standardized to 25,958 for further analysis. Greengenes Database core 16S rRNA reference sequences were used for analysis of taxonomic structure of microbial communities. In total, 46 phyla, 107 classes, 156 orders, 181 families, and 1471 OTUs (97\% sequence similarity cutoff) were classified. OTU numbers of anammox samples ranged from 374 (AN159) to 706 (AN-21) (Table 1). Good's coverage estimates were all $>99 \%$ (Table 1 ), indicating that nearly all bacterial species were included. Detailed phylogenetic analyses for the annotated genera are presented in Fig. S2.

Relative abundance of phyla and dynamic changes in abundance in ANAMMOX reactor are shown in Fig. 2. There were six predominant phyla (Proteobacteria, Chloroflexi, Chlorobi, Planctomycetes, Bacteroidetes, $O D 1$ ), each having average relative abundance $>5 \%$, and sequences of these phyla jointly accounted for 67.6$91.8 \%$ of the total in each sample. Relative abundance of Chloroflexi increased gradually from $12.6 \%$ (day 1 ) to 45.5\% (day 159), then declined to 9.7\% (day 310). Abundance of Proteobacteria decreased from 38.3\% (day 1) to $11.9 \%$ (day 159 ), increased sharply to $34.1 \%$ (day 169 ), then declined again to $16.4 \%$ and stayed in that range. Abundance of Chlorobi rose from 1.7\% (day 1) to $14.5 \%$ (day 58 ), declined gradually to $3.6 \%$ (day 169 ), then increased gradually to $26.9 \%$ (day 310 ). Abundance of Planctomycetes remained very low $(\sim 1.3 \%)$ during days $1-38$, increased gradually to $38.9 \%$ (day 140), declined to $1.9 \%$ (day 169), rose again and stayed steady at $\sim 13.00 \%$ until day 285 , then finally dropped to $\sim 4.8 \%$ and stayed there. Abundance of Bacteroidetes dropped from $26.6 \%$ (day 1 ) to $1.7 \%$ (day 159), increased sharply to $21.2 \%$ (day 169 ), dropped and stayed steady at $\sim 1.7 \%$ until day 219 , then increased gradually to $16.2 \%$ (day $310)$. Abundance of $O D 1$ was low $(\sim 0.9 \%)$ during days $1-109$, increased sharply to $17.9 \%$ on day 123 , declined to $0.8 \%$ on day 169 , rose gradually to $15.3 \%$ on day 297 , then fell to $\sim 4.48 \%$ and stayed there. Pearson test showed that most of these relative abundance values showed significant correlations with nitrogen 
Table 1 OTU richness and diversity indices of bacterial communities in samples

\begin{tabular}{|c|c|c|c|c|c|c|}
\hline Samples $^{\mathrm{a}}$ & OTUs ${ }^{\mathbf{b}}$ & $\mathrm{ACE}$ & Chao1 & Shannon & Simpson & $\begin{array}{l}\text { Good's } \\
\text { coverage } \\
\text { (\%) }\end{array}$ \\
\hline $\mathrm{AN}-1$ & 642 & 736.4 & 778.2 & 6.87 & 0.98 & 99.53 \\
\hline AN-21 & 706 & 833.1 & 865.1 & 6.85 & 0.98 & 99.40 \\
\hline AN-38 & 691 & 805.2 & 822.9 & 6.52 & 0.96 & 99.45 \\
\hline AN-58 & 649 & 779.7 & 806.1 & 6.37 & 0.96 & 99.41 \\
\hline AN-80 & 531 & 672.3 & 664.4 & 5.92 & 0.96 & 99.47 \\
\hline AN-93 & 477 & 601.3 & 596.5 & 6.13 & 0.97 & 99.51 \\
\hline AN-109 & 512 & 624.4 & 621.4 & 6.45 & 0.98 & 99.51 \\
\hline AN-123 & 433 & 555.2 & 558.2 & 5.17 & 0.93 & 99.53 \\
\hline AN-140 & 378 & 494.7 & 474.3 & 4.68 & 0.89 & 99.58 \\
\hline AN-159 & 374 & 477.6 & 458.4 & 5.04 & 0.92 & 99.61 \\
\hline AN-169 & 704 & 795.9 & 831 & 6.99 & 0.98 & 99.51 \\
\hline AN-191 & 377 & 477.4 & 464.3 & 5.00 & 0.92 & 99.61 \\
\hline AN-205 & 404 & 553.1 & 537.2 & 5.20 & 0.94 & 99.51 \\
\hline AN-219 & 391 & 533.5 & 534.5 & 4.79 & 0.91 & 99.52 \\
\hline AN-233 & 690 & 855.0 & 851.3 & 6.25 & 0.96 & 99.30 \\
\hline AN-239 & 455 & 532.5 & 631.9 & 5.33 & 0.95 & 99.42 \\
\hline AN-256 & 442 & 577.1 & 575 & 5.29 & 0.95 & 99.49 \\
\hline AN-271 & 479 & 691.9 & 670.5 & 5.16 & 0.94 & 99.35 \\
\hline AN-285 & 482 & 656.6 & 680.2 & 5.21 & 0.94 & 99.38 \\
\hline AN-297 & 503 & 657.1 & 706.1 & 5.59 & 0.95 & 99.41 \\
\hline AN-310 & 484 & 669.1 & 645.0 & 5.27 & 0.95 & 99.38 \\
\hline
\end{tabular}

a Numbers following "AN" in this column indicate sampling date (day)

b $97 \%$ similarity cutoff

concentration (influent ammonia, influent nitrite, effluent nitrate) and nitrogen removal efficiency (Table 2). The two major phyla in SHARON reactor, accounting for $63.6-77.3 \%$ of total, were Bacteroidetes and Proteobacteria (Fig. 2). When SHARON effluent was introduced as ANAMMOX influent, bacteria in SHARON effluent had little or no effect on the anammox community; only a slight increase in Bacteroidetes abundance in later stages was observed (Fig. 2).

Nearly all bacteria belonging to phylum Planctomycetes detected on or after day 38 were anammox bacteria, as detailed below. During the early startup period (days 1-38), relative abundance of Planctomycetes remained at a constant low level $(\sim 1.3 \%)$, Chloroflexi and Chlorobi increased, and Proteobacteria and Bacteroidetes declined. During the entire running period, Planctomycetes abundance was significantly correlated with influent nitrite and effluent nitrate levels (Table 2). Among the phyla with average relative abundance $>1 \%$, Planctomycetes showed positive correlation with Chloroflexi $(R=0.36, p<0.05)$ and Acidobacteria $(R=0.38, p<0.05)$, and negative correlation with Proteobacteria $(R=-0.69$, $p<0.001)$ and Bacteroidetes $(R=-0.62, p<0.001)$ (Additional file 1: Fig. S3).

\section{Bacterial diversity}

In the course of the entire running period, ANAMMOX community diversity underwent an initial decrease, then a slight increase, and finally a second decrease to a level at which it remained stable. The Shannon index decreased gradually from 6.87 (day 1) to 4.68 (day 140; minimal value), increased to 6.25 (day 233), then declined to $\sim 5.31$ and stayed there (Table 1). Pearson's test between nitrogen concentration (influent ammonia, influent nitrite and effluent nitrite) and $\alpha$-diversity showed that nitrogen concentration significantly negative correlated to $\alpha$-diversity (Additional file 1: Table S2).

In PCoA, the 21 ANAMMOX samples were consistently along the first and second principal coordinates (PC1: 54.40\%; PC2: 27.01\%), with the exception of samples AN-169 and AN-233 (Fig. 3). The samples generally deviated from sample AN-1 to sample AN-159 gradually along the two PCoA principal coordinates, with stepwise increase of nitrogen load from $\mathrm{NH}_{4}{ }^{+}-\mathrm{N} 50 \mathrm{mg} / \mathrm{L} /$ $\mathrm{NO}_{2}{ }^{-}-\mathrm{N} 55 \mathrm{mg} / \mathrm{L}$ to $\mathrm{NH}_{4}{ }^{+}-\mathrm{N} 272.7 \mathrm{mg} / \mathrm{L} / 300 \mathrm{mg} / \mathrm{L}$ during day 1-160. With nitrogen load increase to $\mathrm{NH}_{4}{ }^{+}-\mathrm{N} 300 \mathrm{mg} / \mathrm{L} / \mathrm{NO}_{2}{ }^{-}-\mathrm{N} 330 \mathrm{mg} / \mathrm{L}$ during day $161-$ 187, sample AN-169 clustered back to AN-1 AN-58. Decrease influent load to $\mathrm{NH}_{4}{ }^{+}-\mathrm{N} 272.7 \mathrm{mg} / \mathrm{L} / \mathrm{NO}_{2}{ }^{-}-\mathrm{N}$ 


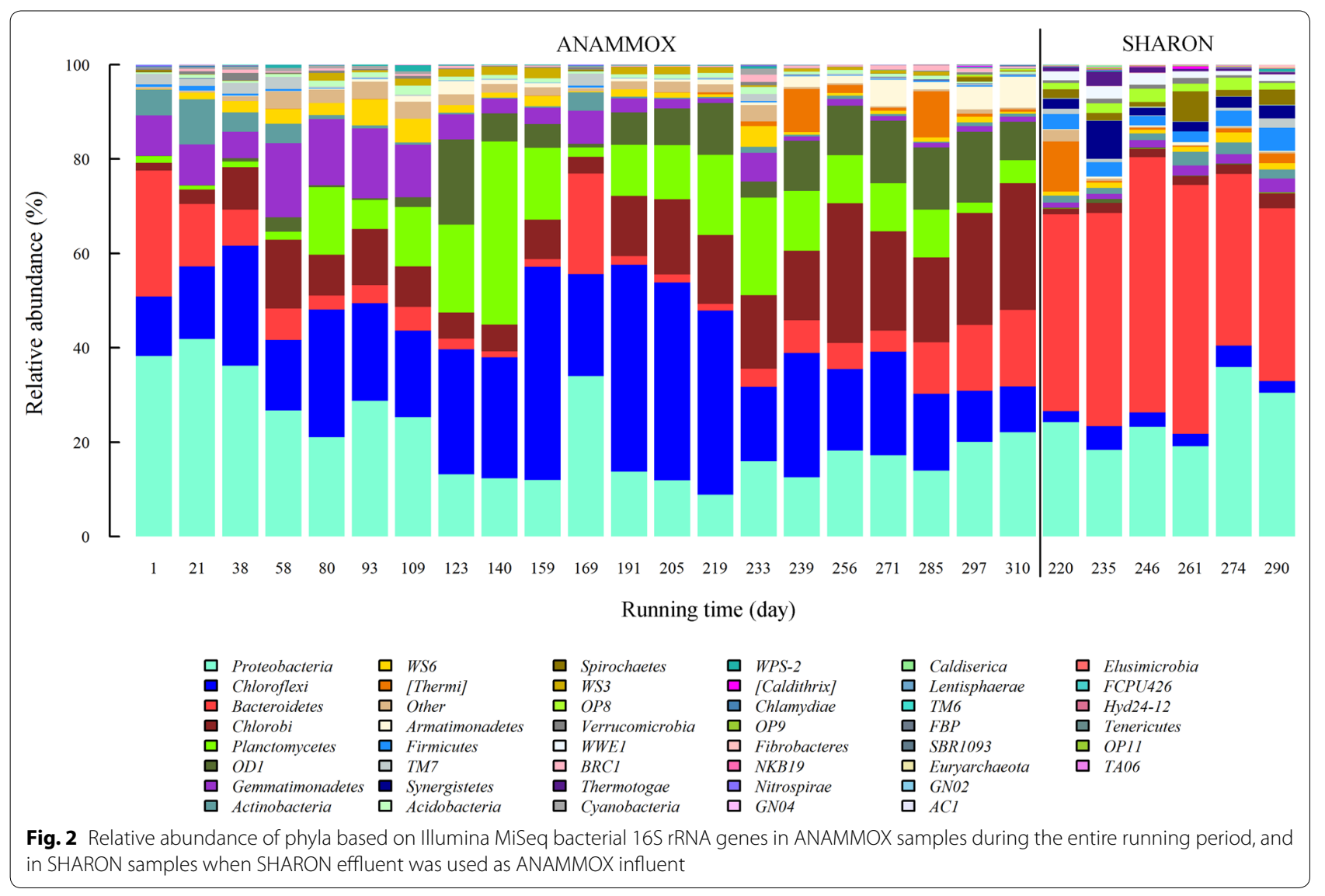

Table 2 Correlation ( $R$ value) of relative abundance of major phyla to nitrogen compounds

\begin{tabular}{|c|c|c|c|c|c|c|c|c|}
\hline \multirow[t]{2}{*}{ Phylum } & \multicolumn{2}{|l|}{$\mathrm{NH}_{4}^{+}-\mathrm{N}$} & \multicolumn{2}{|l|}{$\mathrm{NO}_{2}{ }^{-}-\mathrm{N}$} & \multirow[t]{2}{*}{$\mathrm{NO}_{3}{ }^{-}-\mathrm{N}$ effluent } & \multirow[t]{2}{*}{$\mathrm{NH}_{4}^{+}-\mathrm{N}$ removal } & \multirow[t]{2}{*}{$\mathrm{NO}_{2}{ }^{-}-\mathrm{N}$ removal } & \multirow{2}{*}{$\begin{array}{l}\text { Total } \\
\text { nitrogen } \\
\text { removal }\end{array}$} \\
\hline & influent & effluent & influent & effluent & & & & \\
\hline Chloroflexi & 0.18 & -0.30 & 0.28 & -0.12 & $0.48^{*}$ & 0.33 & 0.27 & 0.27 \\
\hline Proteobacteria & $-0.72^{* * *}$ & -0.012 & $-0.79^{* * *}$ & -0.048 & $-0.69^{* * *}$ & $-0.64^{* *}$ & $-0.66^{* *}$ & $-0.67^{* * *}$ \\
\hline Chlorobi & $0.63^{* * *}$ & 0.35 & $0.47^{*}$ & 0.14 & 0.22 & 0.29 & 0.39 & 0.38 \\
\hline Planctomycetes & 0.31 & 0.044 & $0.48^{*}$ & 0.083 & $0.49^{*}$ & 0.32 & 0.36 & 0.33 \\
\hline Bacteroidetes & -0.21 & 0.22 & -0.29 & 0.19 & -0.38 & $-0.54^{*}$ & $-0.57^{* *}$ & $-0.54^{*}$ \\
\hline OD1 & $0.74^{* * *}$ & 0.062 & $0.72^{* * *}$ & 0.20 & 0.43 & 0.41 & 0.36 & 0.43 \\
\hline Gemmatimonadetes & $-0.76^{* * *}$ & -0.38 & $-0.75^{* * *}$ & $-0.44^{*}$ & $-0.47^{* *}$ & -0.051 & -0.023 & -0.037 \\
\hline Armatimonadetes & $0.61^{* *}$ & 0.20 & $0.48^{*}$ & 0.15 & 0.23 & 0.23 & 0.29 & 0.31 \\
\hline Actinobacteria & $-0.71^{* * *}$ & 0.055 & $-0.73^{* * *}$ & 0.11 & $-0.74^{* * *}$ & $-0.74^{* * *}$ & $-0.79^{* * *}$ & $-0.76^{* * *}$ \\
\hline WS6 & -0.33 & -0.16 & -0.33 & -0.16 & -0.086 & 0.16 & 0.27 & 0.18 \\
\hline [Thermi] & 0.28 & 0.023 & 0.41 & 0.24 & 0.069 & 0.15 & 0.085 & 0.16 \\
\hline
\end{tabular}

${ }^{*} p<0.05 ;{ }^{* *} p<0.01 ;{ }^{* * *} p<0.001$

$300 \mathrm{mg} / \mathrm{L}$ during day 188-228, samples deviated again along the two PCoA principal coordinates following samples AN-123 AN-159. When SHARON effluent was used as ANAMMOX influent during days 229-314, samples deviated a little along the first principal coordinates and clustered together, but AN-233 clustered back to AN-80 and AN-93. The six SHARON samples clustered together, far away from the ANAMMOX samples, consistently with microbial community composition as shown in Fig. 2. 


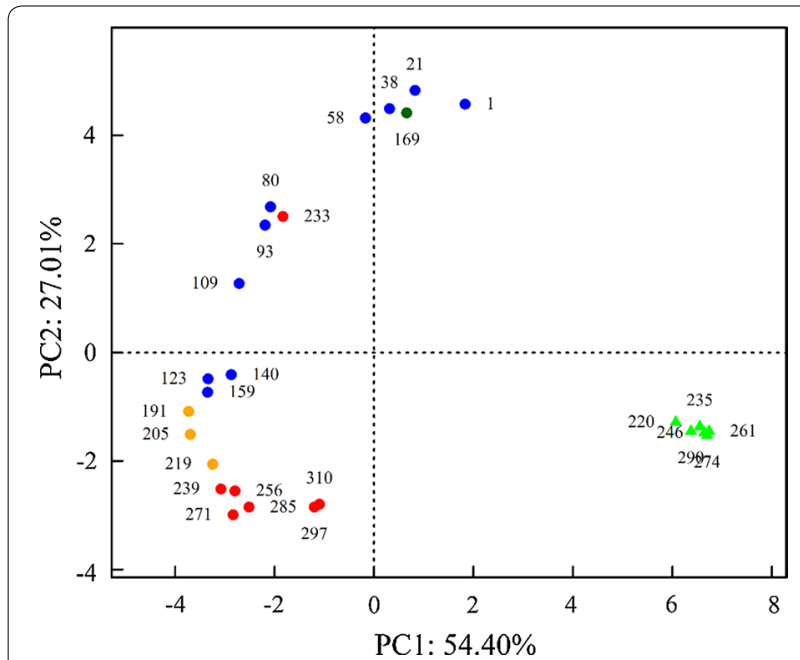

Fig. 3 Principal Coordinates Analysis (PCoA) based on Bray-Curtis distance from bacterial $16 \mathrm{~S}$ rRNA gene sequences. Samples were simply represented by the numbers showing the sampling dates. Triangles: samples from SHARON reactor. Circles: samples from ANAMMOX reactor. Blue: samples obtained with influent load stepwise increased from $\mathrm{NH}_{4}{ }^{+}-\mathrm{N} 50 \mathrm{mg} / \mathrm{L} / \mathrm{NO}_{2}{ }^{-}-\mathrm{N} 55 \mathrm{mg} / \mathrm{L}$ to $\mathrm{NH}_{4}{ }^{+}-\mathrm{N} 272.7 \mathrm{mg} / \mathrm{L} / 300 \mathrm{mg} / \mathrm{L}$ (days 1-160); Bottle-green: samples obtained with influent load $\mathrm{NH}_{4}{ }^{+}-\mathrm{N} 300 \mathrm{mg} / \mathrm{L} / \mathrm{NO}_{2}{ }^{-}-\mathrm{N} 330 \mathrm{mg} / \mathrm{L}$ (days 161-187); Orange: samples obtained with influent load $\mathrm{NH}_{4}{ }^{+}-\mathrm{N} 272.7 \mathrm{mg} / \mathrm{L} / \mathrm{NO}_{2}{ }^{-}-\mathrm{N} 300 \mathrm{mg} / \mathrm{L}$ (days 188-228); Red: samples obtained with SHARON effluent used as influent $\mathrm{NH}_{4}{ }^{+}-\mathrm{N} \sim 300 \mathrm{mg} / \mathrm{L} /$ $\mathrm{NO}_{2}{ }^{-}-\mathrm{N} \sim 300 \mathrm{mg} / \mathrm{L}$ (days 229-310)
In RDA, influent ammonia $\left(r^{2}=0.660, p<0.001\right)$, influent nitrite $\left(r^{2}=0.615, p<0.001\right)$, and effluent nitrate $\left(r^{2}=0.523, p<0.01\right)$ collectively drove microbial community successions (Fig. 4a). VPA showed that either influent ammonia or influent nitrite explained 33\% of community dynamics, whereas effluent nitrate explained 22\% (Fig. 4b). These three main parameters collectively contributed to $43 \%$ of microbial community dynamics (Fig. 4b), while the remaining 57\% was not explained. Other running parameters not shown here, e.g. effluent ammonia, effluent nitrite, $\mathrm{pH}$ and $\mathrm{DO}$, contributed little to microbial community dynamics. Mantel test revealed significant correlation between community dynamics and nitrogen removal capability $(r=0.489, p<0.001)$.

\section{Anammox bacteria and nitrifying bacteria}

A heatmap based on annotated genera showed that the two predominant genera in ANAMMOX reactor were Candidatus Brocadia and an unclassified genus related to Ca. Kuenenia (Fig. S2). Relative abundance of total anammox bacteria became detectable since day 38 with relative abundance $0.03 \%$, increased rapidly to $0.9 \%$ on day 58 , increased gradually to $38.4 \%$ on day 140 , decreased to $0.4 \%$ on day 169 , increased to $19.2 \%$ on day 233 , remained at $\sim 9.0 \%$ until day 285 , declined to $1.1 \%$ on day 297 , and then increased to $3.3 \%$ on day 310 (Fig. 5). Relative abundance values and variation trends

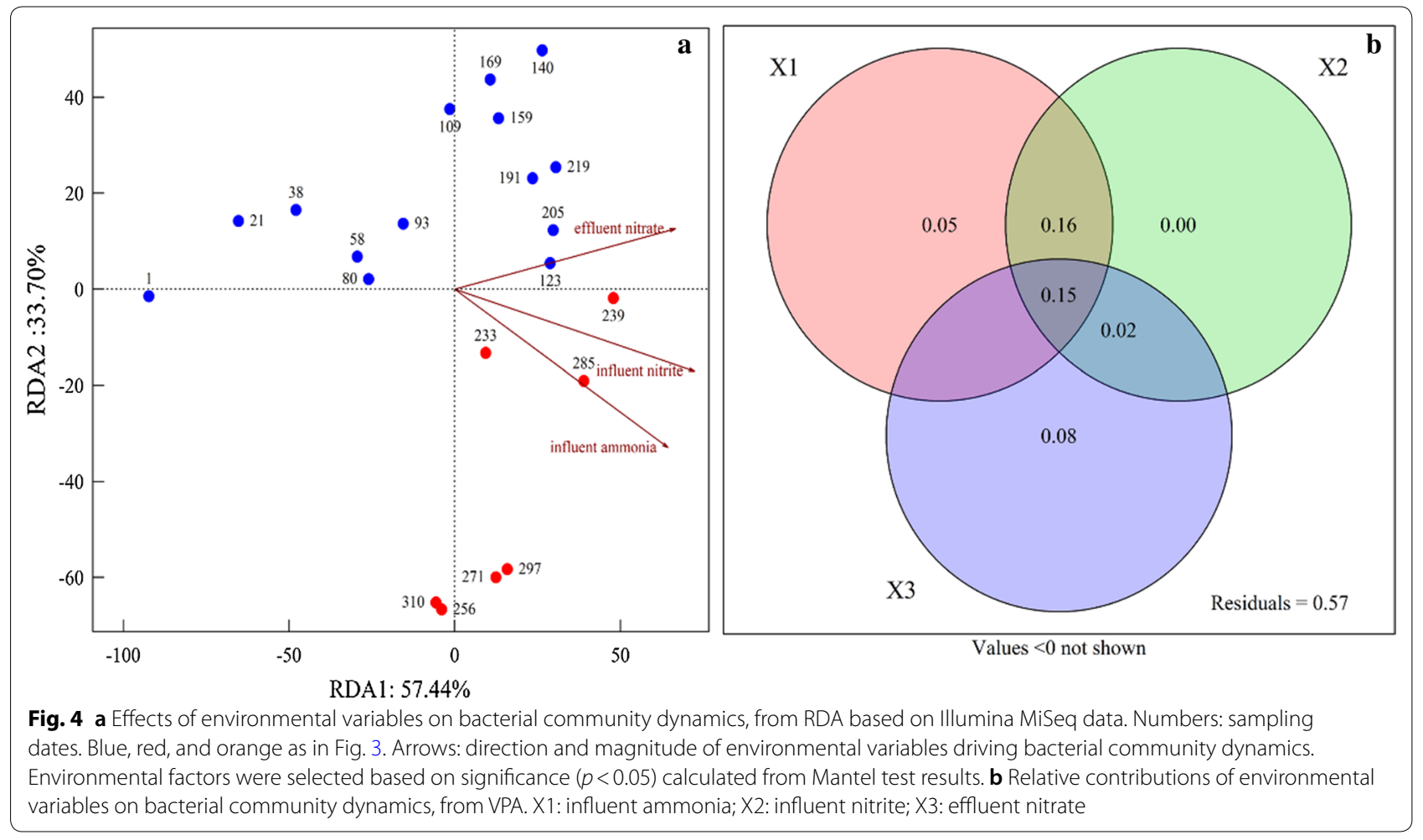




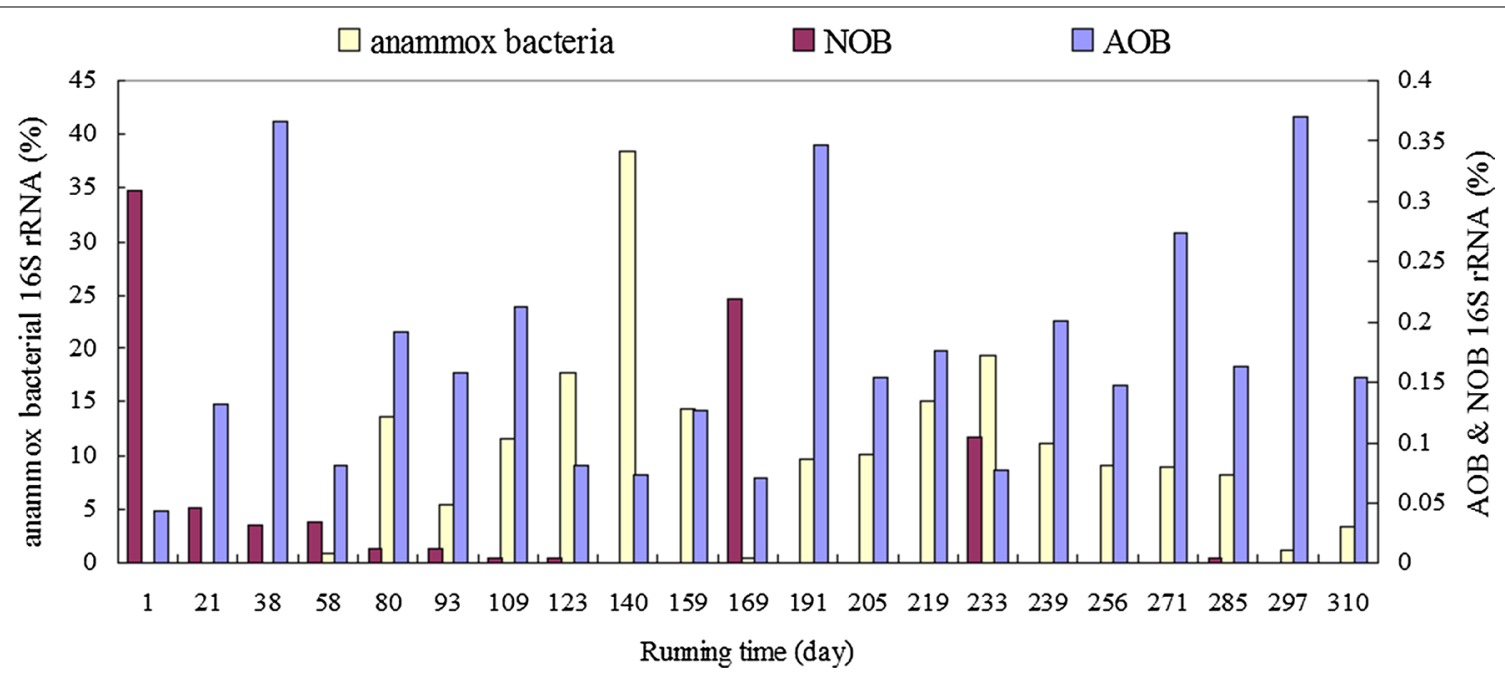

Fig. 5 Relative abundance of sequences related to anammox bacteria, NOB, and AOB in ANAMMOX, from bacterial 16S rRNA gene sequences

for total anammox bacteria were quite similar to those for Planctomycetes as described above.

Seven anammox OTUs in total were defined. A phylogenetic tree was constructed based on these OTUs, which clustered into two groups: a Ca. Brocadiarelated group (OTU-14, OTU-21, OTU-651, OTU-902, OTU-977 and OTU-1471) and a Ca. Kuenenia-related group (OTU-19) (Fig. 6a). The Ca. Kuenenia-related group was consistent with the unclassified genus seen in the heatmap (Additional file 1: Fig. S2). During the entire running period, among genera with average relative abundance $>0.05 \%, C a$. Brocadia-related group was positively correlated with genus $\operatorname{Dok} 59(R=0.43$, $p<0.05$ ), which accounted for $0.4-4.8 \%$ of $16 \mathrm{~S}$ rRNA sequences in each sample, but negatively correlated with genera Gemmatimonas $(R=-0.38, p<0.05)$ and Thermomonas $(R=-0.40, p<0.05)$. Ca. Kueneniarelated group was negatively correlated with genera Dok59 $(R=-0.54, p<0.01)$, Caldilinea $(R=-0.44$, $p<0.05)$, Bdellovibrio $(R=-0.39, p<0.05)$, and Opitutus $(R=-0.41, p<0.05)$.

Among the seven anammox OTUs, the predominant ones were OTU-14 (97.7\% sequence similarity to Ca. Brocadia fulgida), OTU-19 (98.9\% similarity to Ca. Kuenenia stuttgartiensis), OTU-21 (99.5\% similarity to Ca. B. sinica), and OTU-651 (97.9\% similarity to Ca. B. caroliniensis) (Fig. 6b). The other three OTUs, OTU-902 (95.1\% similarity to Ca. B. fulgida), OTU977 (96.5\% similarity to Ca. B. fulgida), and OTU1471 (94.8\% similarity to Ca. B. fulgida) remained at nearly undetectable level throughout the entire running period. In the phylogenetic tree, among $\mathrm{Ca}$. Brocadiarelated group members, OTU-14, -902, and -1471 clustered together to form a subgroup far away from others, and OTU-977 was on a branch by itself.

During the period of increasing influent load (days 1-228), OTU-14 was positively correlated with influent nitrite $(R=0.54, p<0.05)$, and OTU-21 was negatively correlated with effluent ammonia $(R=-0.55, p<0.05)$. OTU-19 and OTU-651 showed no significant correlation with nitrogen compounds. During the subsequent experimental period (days 229-314), the four major OTUs showed no significant correlation with influent or effluent nitrogen compounds.

Relative abundance of the various anammox OTUs underwent dynamic changes. OTU-14, -21, and -651 showed increases from initially undetectable levels during days 1-37, consistently with reactor performance during this period. These three OTUs had similar abundance trends until day 93, dropped greatly on day 169 , and showed differing trends thereafter. Abundance of OTU-14 was near zero during days 1-37, increased sharply to $3.6 \%$ on day 80 , dropped to $2.0 \%$ on day 93 , increased gradually to $29.6 \%$ on day 140 , dropped to $0.3 \%$ on day 169 , increased to $6.5 \%$ on day 219 , dropped to $0.4 \%$ on day 297 , and finally increased to $1.1 \%$. Abundance of OTU-21 increased from $0.6 \%$ on day 58 to $7.2 \%$ on day 80 , dropped to $\sim 3.0 \%$ and stayed there until day 159 , dropped further to $0.1 \%$ on day 169 , increased to $12.3 \%$ on day 233 , declined gradually to $0.1 \%$ on day 297 , and then increased slightly to $0.2 \%$. Abundance of OTU651 increased from near zero to $2.7 \%$ during days $1-80$, decreased to $1.4 \%$ on day 93 , increased gradually to $7.2 \%$ on day 123 , declined to $0.04 \%$ on day 169 , and remained at nearly undetectable level thereafter, except for a value of $4.0 \%$ on day 233. Despite the fluctuations of the three 


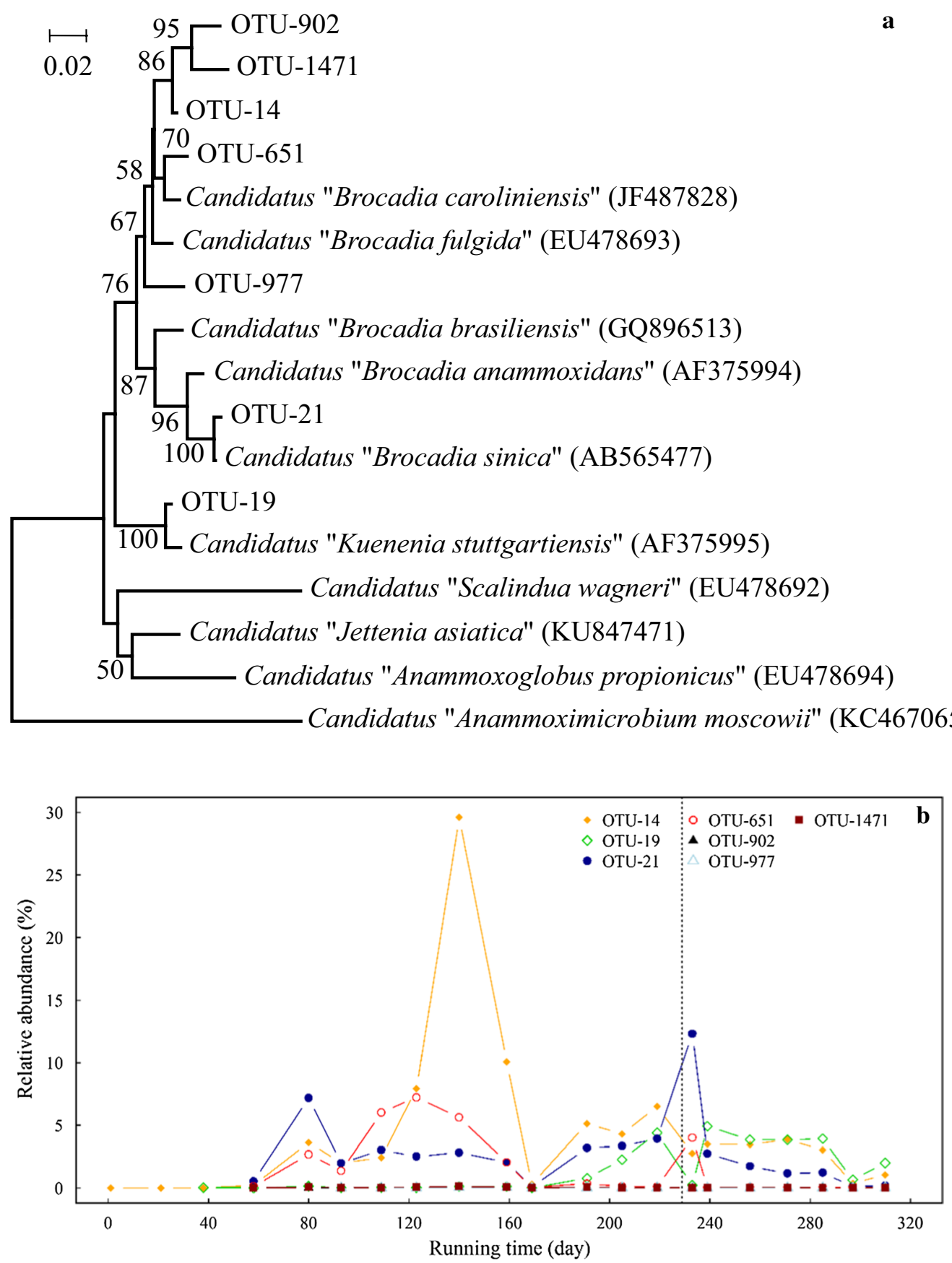

Fig. 6 a Neighbor-joining tree of anammox bacterial OTUs, based on 165 rRNA gene fragments. Bootstrap values (> 50\%) shown on branch nodes are based on 1000 trials. Bar: evolutionary distance 0.01. b Relative abundance of these OTUs during the entire running period. Dotted line as in Fig. 1

individual OTUs, their combined relative abundance showed an overall increasing trend, consistent with reactor performance during days 1-140 (Fig. 1).

In regard to influent loads (Fig. 1), the three major anammox bacteria as described above were slightly inhibited by differing loads: $\mathrm{NH}_{4}{ }^{+}-\mathrm{N} 150 \mathrm{mg} / \mathrm{L} /$
$\mathrm{NO}_{2}{ }^{-}-\mathrm{N} 165 \mathrm{mg} / \mathrm{L}$ for Ca. B. sinica (OTU-21), $\mathrm{NH}_{4}{ }^{+}-\mathrm{N}$ $272.7 \mathrm{mg} / \mathrm{L} / \mathrm{NO}_{2}{ }^{-}-\mathrm{N} 300 \mathrm{mg} / \mathrm{L}$ for $C a$. B. caroliniensis (OTU-651), and $\mathrm{NH}_{4}{ }^{+}-\mathrm{N} 300 \mathrm{mg} / \mathrm{L} / \mathrm{NO}_{2}{ }^{-}{ }^{-} \mathrm{N} 330 \mathrm{mg} / \mathrm{L}$ for Ca. B. fulgida (OTU-14) (Figs. 1, 5). All three of the above bacteria were greatly inhibited by load $\mathrm{NH}_{4}{ }^{+}-\mathrm{N}$ $300 \mathrm{mg} / \mathrm{L} / \mathrm{NO}_{2}{ }^{-}-\mathrm{N} 330 \mathrm{mg} / \mathrm{L}$. On the other hand, Ca. B. 
fulgida and Ca. B. sinica recovered from nitrite inhibition after day 169 when influent load dropped, whereas $C a$. $B$. caroliniensis did not (Fig. 5). OTU-19, closely related to Ca. K. stuttgartiensis, remained at undetectable level during days $1-169$, increased to $4.4 \%$ on day 219 , dropped to $0.2 \%$ on day 233 , increased to $4.9 \%$ on day 239 , remained at $4.0 \%$ until day 285 , dropped to $0.7 \%$ on day 297 , and then increased to $2.0 \%$ on day 310 (Fig. 6b). Trends of relative abundance for OTU-14 and OTU-19 were similar from day 169 onward $(R=0.53, p<0.05)$. SHARON effluent was introduced as ANAMMOX influent on day 229. Resulting decrease of $\mathrm{Ca}$. B. sinica-related OTUs was stronger than those of Ca. B. fulgida- and Ca. K. stuttgartiensis-related OTUs.

Nitrifying bacteria, including ammonia oxidizing bacteria $(\mathrm{AOB})$ and nitrite oxidizing bacteria $(\mathrm{NOB})$, were all detected in the present study (Fig. 5, Additional file 1: Fig. S4). Seven AOB OTUs in total were detected with low relative abundance (0.04-0.36\%; Fig. 5), and clustered into three groups: Nitrosomonas oligotropharelated group (OTU-831, OTU-1151), N. ureae-related group (OTU-1242), and $N$. europaea-related group (OTU-63, OTU-122, OTU-142, OTU-440) (Additional file 1: Fig. S4A). The $N$. ureae- and N. oligotropha-related groups were detected respectively during days $1-58$ and days $1-80$, and remained at undetectable levels thereafter (Additional file 1: Fig. S4B). The N. europaea-related group was detected during the entire running period: OTU-122 and -440 during days 1-123, OTU-122 during days $124-219$, and OTU-63 and -122 during days $220-$ 310 (Fig. S4B). Four NOB OTUs (OTU-329, -760, -855, $-1157)$ with low relative abundances $(0-0.27 \%$, Fig. 5) were detected, with Nitrospira being the predominant genus. Relative abundance of total NOB in our study was dynamic, ranging from 0 to $0.27 \%$ during the entire running period, e.g., $\sim 0.27 \%$ on day $1, \sim 0.21 \%$ on day 169 , and $\sim 0.1 \%$ on day 233 .

\section{Discussion}

To date, little attention has been given to microbial community dynamics in an ANAMMOX reactor including rapid startup, increasing nitrogen load and stable performance (Costa et al. 2014; Liu et al. 2017). A combined system "UASB + SHARON + ANAMMOX" was built for treating piggery wastewater, microbial community dynamics in ANAMMOX reactor were explored using Illumina MiSeq method during the whole running period. Interdependencies of microbial community and running parameters were also elucidated in this study.

\section{Performance of ANAMMOX reactor}

In this study, the ANAMMOX reactor exhibited nitrogen removal ability on day 38 , and was successfully started up on day 55; and this performance was well associated with the increase of relative abundance of anammox bacteria. This startup time was much shorter than those in previous reports (e.g., Trigo et al. 2006; Ni and Zhang 2013). This might be due to the shortened doubling time of anammox bacteria with appropriate running parameters designed, e.g. low load, long HRT, appropriate temperature and running manner (Tang et al. 2011). Under such operating conditions, some bacterial taxa increased in relative abundance while others dropped, forming appropriate ecological niches for anammox bacteria (Finlay et al. 1997). Though anammox bacteria were present in the seeding sludge as rare/cryptic microbial species, the nitrogen removal efficiency appeared on day 38 . That was because anammox biomass accumulation was necessary to achieve the cell density $10^{10}-10^{11}$ cells $\mathrm{mL}^{-1}$, the minimal density required for appreciable nitrogen removal activity (Strous et al. 1999).

Anammox bacteria were the key factor for nitrogen removal performance, and they were affected by influent load dramatically. Anammox bacteria adapted to the increasing nitrogen loads and accumulated its biomass after acclimation, improving nitrogen removal efficiency gradually. However, anammox bacterial growth and nitrogen removal efficiency were adversely inhibited when nitrogen load reached to a certain inhibitory value, and this inhibition could be relieved by reducing influent load to that lower than the inhibitory threshold. The inhibitory effect of nitrite on anammox bacteria is much stronger than that of ammonia (Isaka et al. 2007; Van Hulle et al. 2010). The actual anammox inhibitor is FNA (free nitrous acid) rather than nitrite, and $\mathrm{pH}$ greatly affected $\mathrm{FNA} /$ nitrite equilibrium (Fernández et al. 2012). An increase of influent $\mathrm{NO}_{2}{ }^{-}-\mathrm{N}$ from 55 to $300 \mathrm{mg} / \mathrm{L}$ resulted in increase of FNA from $\sim 1.7 \mu \mathrm{g} / \mathrm{L}$ to $\sim 8.7 \mu \mathrm{g} / \mathrm{L}$, but the growth of anammox bacteria and reactor performance were not affected too much. However, anammox activity and nitrogen removal efficiency were impaired seriously, resulted from the increased FNA content to $\sim 9.6 \mu \mathrm{g} / \mathrm{L}$ with influent $\mathrm{NO}_{2}{ }^{-} \mathrm{N} 330 \mathrm{mg} / \mathrm{L}$. Inhibitory nitrite concentration in the present study was lower than the hemi-inhibitory concentration (50\% activity loss; IC50) of $11 \mu \mathrm{g} / \mathrm{L}$ reported by Fernández et al. (2012). Anammox performance improved when influent load decreased again to $\mathrm{NO}_{2}{ }^{-}-\mathrm{N} 300 \mathrm{mg} / \mathrm{L}$, consistently with the findings of Tang et al. (2010). Nitrite in SHARON effluent was $\mathrm{NO}_{2}{ }^{-}-\mathrm{N} \sim 300 \mathrm{mg} / \mathrm{L}$, but FNA content dropped to $\sim 4.0 \mu \mathrm{g} / \mathrm{L}$ due to its high alkaline $(\mathrm{pH} \sim 8.2)$. Nitrite inhibition on anammox bacteria could be alleviated for treating pre-treated piggery wastewater. 


\section{Community dynamics}

ANAMMOX bacteria, members of Planctomycetes, were the functional group in ANAMMOX reactor, and heterotrophic bacteria were also important to ensure its performance (Cho et al. 2010; Finlay et al. 1997), but the microbial community compositions were influenced greatly by influent loads. Increasing influent load stepwise from $\mathrm{NH}_{4}{ }^{+}-\mathrm{N} 50 \mathrm{mg} / \mathrm{L} / \mathrm{NO}_{2}{ }^{-}-\mathrm{N} 55 \mathrm{mg} / \mathrm{L}$ to $\mathrm{NH}_{4}{ }^{+}-\mathrm{N} 272.7 \mathrm{mg} / \mathrm{L} / \mathrm{NO}_{2}{ }^{-}-\mathrm{N} 300 \mathrm{mg} / \mathrm{L}$ (days 1-160), nitrogen removal efficiency were enhanced gradually with the relative abundance of Planctomycetes, Chloroflexi and OD1 increased while Proteobacteria and Bacteroidetes dropped. However, with influent load $\mathrm{NH}_{4}{ }^{+}-\mathrm{N}$ $300 \mathrm{mg} / \mathrm{L} / \mathrm{NO}_{2}{ }^{-}-\mathrm{N} 330 \mathrm{mg} / \mathrm{L}$ (day 161-187), microbial community compositions were changed greatly, and similar to those during days 1-58. Though nitrogen removal ability was impaired seriously, it was still much higher than that during days 1-58. That was probably because the state of Planctomycetes had been changed during the long-period acclimation, and high anammox activity was reserved (Casadesús and D'Ari 2002; Wolf et al. 2010). Reducing the influent load to $\mathrm{NH}_{4}{ }^{+}-\mathrm{N}$ $272.7 \mathrm{mg} / \mathrm{L} / \mathrm{NO}_{2}{ }^{-}-\mathrm{N} 300 \mathrm{mg} / \mathrm{L}$ (days 188-228), microbial community composition and nitrogen removal rate were similar to those on day 159 . With SHARON effluent used as influent since day 229 , microbial community and nitrogen removal efficiency on day 233 were similar to those during days 80-93. After acclimation, relative abundance of Planctomycetes dropped, but the increase of Chloroflexi might enhance the distributed nitrite loop with Planctomycetes, promoting the nitrogen removal efficiency (Lawson et al. 2017). These newly formed microbial communities were more suitable for treating pre-treated piggery wastewater.

Relative abundance of Planctomycetes was significantly correlated with influent nitrite and effluent nitrate levels (Table 2). Similarly, previous studies showed that nitrite was not only a substrate but also an inhibitor for anammox bacteria (Jin et al. 2012; Strous et al. 1998), and oxidation of nitrite to nitrate supplied reducing power for $\mathrm{CO}_{2}$ fixation, as reflected to some degree in bacterial growth (Strous et al. 2006). Notably, its relative abundance dropped greatly to $0.4 \%$ on day 169 due to inhibition caused by high nitrite load $\left(\mathrm{NH}_{4}{ }^{+}-\mathrm{N} 300 \mathrm{mg} / \mathrm{L} /\right.$ $\mathrm{NO}_{2}{ }^{-}-\mathrm{N} 330 \mathrm{mg} / \mathrm{L}$ ) (Jin et al. 2012), and this kind inhibition was relieved through reducing influent load (Kimura et al. 2010). Planctomycetes showed significant correlation with Chloroflexi $(R=0.36, p<0.05)$, Acidobacteria $(R=0.38, p<0.05)$, Proteobacteria $(R=-0.69, p<0.001)$ and Bacteroidetes $(R=-0.62, p<0.001)$ (Additional file 1: Fig. S3), and these microbes helped the formation of a suitable ecological niche for anammox bacteria resulting from constant acclimatization to mineral influent (Finlay et al. 1997). Considering the relationship between these taxa and nitrogen removal efficiency, decline of Proteobacteria and Bacteroidetes might favor the nitrogen removal efficiency, while Chloroflexi and Acidobacteria contributed little.

Proteobacteria are commonly present in ANAMMOX reactors (Costa et al. 2014; Date et al. 2009; Li et al. 2009). Members of this group are physiologically diverse (including aerobic, anaerobic, microaerobic, and facultatively aerobic forms) and thus able to adapt to a variety of habitats. The oxygen-consuming forms may help create anaerobic environments suitable for anammox bacteria. Members of phylum Chloroflexi were reported to feed on lysed anammox bacterial cells and contribute to formation of granular sludge with filamentous structure (Kindaichi et al. 2012; Yamada et al. 2005). Members of Acidobacteria, Bacteroidetes and Chlorobi are always present in ANAMMOX reactors, metabolic activities and interactions between anammox and these heterotrophic bacteria were critical in maintaining the stability of its performance (Lawson et al. 2017).

\section{Bacterial diversity}

Reduced bacterial diversity may result from long-term acclimatization with mineral influent and elimination of unsuitable microorganisms to reach a new equilibrium (Kinnunen et al. 2016). Stepwise increased nitrogen load may open niches for nitrogen metabolism-related organisms, with the microbial community thereby becoming more efficient in nitrogen removal at higher capacity (Finlay et al. 1997). With the period of acclimation in high nitrogen load, microbial diversity and nitrogen removal efficiency on day 169 and 233 quickly recovered, reflecting the strong flexibility of the microbial community in response to external environmental conditions (Casadesús and D’Ari 2002; Finlay et al. 1997). Previous study has revealed that strong effects of ammonia, nitrite, and nitrate levels on anammox community structure (Sun et al. 2014). Community dynamics may also be driven by other influent materials or by environmental factors for the three major running parameters explained $43 \%$ of microbial community dynamics (Fig. 4b). Comprehensive evaluation of relationships among microbial community dynamics, nitrogen removal capacity and various environmental conditions will help to determine the optimal running parameters for rapid startup and high efficiency.

\section{Anammox bacteria, $\mathrm{AOB}$ and NOB}

Anammox bacteria, only $\mathrm{Ca}$. Brocadia-related group and Ca. Kuenenia-related group detected, comprised $\sim 98.7 \%$ of the phylum Planctomycetes, similarly to previous findings in the range $87-99.5 \%$ (Li et al. 2016). Notably, OTU-14/902/1471 and OTU-977 may constitute two 
novel species of the genus Ca. Brocadia. Their relative abundances were very low during the entire running period, presuming that suitable ecological niches for these taxa were not formed in the ANAMMOX reactor.

Dynamic changes of $\mathrm{Ca}$. B. fulgida (OUT-14), Ca. B. sinica (OTU-21) and Ca. B. caroliniensis (OTU-651) due to stepwise increasing load during days 1-140 suggested that the three anammox bacteria in aerobic sludge attained their ecological niches and adapted to the anaerobic habitat to successfully start up the ANAMMOX reactor (Kinnunen et al. 2016). Considering the impact from influent load, the three major anammox bacteria as described above were slightly inhibited by differing loads (Figs. 1, 6). Numerous studies have shown that ANAMMOX processes are inhibited more strongly by nitrite than by ammonia, but reported threshold values vary widely, from 5 to $280 \mathrm{mg} / \mathrm{L} \mathrm{NO}_{2}{ }^{-}-\mathrm{N}$ (Isaka et al. 2007; Van Hulle et al. 2010). Community dynamics of anammox bacteria in response to stepwise increasing nitrogen load as observed in the present study may help clarify apparent discrepancies regarding enrichment of various anammox bacteria under differing running conditions (particularly nitrite content), and differing inhibitory nitrite levels for various anammox bacteria. Nitrogen load $\mathrm{NH}_{4}{ }^{+}-\mathrm{N} 300 \mathrm{mg} / \mathrm{L} / \mathrm{NO}_{2}{ }^{-}-\mathrm{N} 330 \mathrm{mg} / \mathrm{L}$ was the maximum inhibitory concentration, in agreement with the previous report that $\mathrm{NO}_{2}{ }^{-}-\mathrm{N} 280 \mathrm{mg} / \mathrm{L}$ should be considered a warning value (Jin et al. 2012). The nitrite inhibition was relieved when influent load dropped, which was consistent with previous research (Kimura et al. 2010), but not for all anammox bacteria in this study.

Ca. K. stuttgartiensis (OTU-19) was detected and increased since day 169 (Fig. 6b). An ecological niche defined by high nitrogen load may be necessary for growth of OTU-19, since Ca. K. stuttgartiensis was frequently detected in ANAMMOX reactors with high nitrogen load in previous studies ( $\mathrm{Li}$ et al. 2009; Wang et al. 2013). Relative abundance for OTU-14 and OTU-19 were correlated from day 169 onward $(R=0.53, p<0.05)$, suggesting that their ecological niches and/or physiological functions are similar, and differ from those of $C a$. B. sinica. Ca. B. fulgida and Ca. K. stuttgartiensis both responded to iron accumulation in ANAMMOX reactor, which was reported previously to be a stimulatory factor for growth of anammox bacteria (van Niftrik et al. 2008; Zhang et al. 2009).

Total relative abundance of anammox bacteria dropped to $<10 \%$ and OTU relative abundance fluctuated greatly when using SHARON effluent since day 229. Interestingly, nitrogen removal rate was barely affected after acclimation, resulting from the higher anammox activities of Ca. B. fulgida, Ca. B. sinica and Ca. K. stuttgartiensis besides the distributed nitrite loop described above. Decrease of $C a$. B. sinica-related OTUs was stronger than those of Ca. B. fulgida- and Ca. K. stuttgartiensis-related OTUs, speculating that $C a$. B. sinica has greater sensitivity to SHARON effluent. Similar relative abundance of anammox bacteria was also detected previously when ANAMMOX reactors were fed with pre-treated wastewater from partial nitrification [7.9\%, Dosta et al. (2015); $0.3 \%$, Wang et al. (2016)]. The decline of relative abundance of anammox bacteria might be due to the ambiguous compositions in piggery wastewater, e.g., antibiotics, heavy metals, phosphate and sulfide (Bernet et al. 2000; Tang et al. 2011; Tong et al. 2009; Jin et al. 2012). Previous studies demonstrated the complexity of components in SHARON effluent, and sensitivity of anammox activity to external interference at high influent load (Fernández et al. 2012; Krümmel and Harms, 1982). However, such external interference is presumably not due to organic materials, since they are removed efficiently during UASB and SHARON processes, as indicated by very low COD content of SHARON effluent (data not shown). Values of DO and $\mathrm{pH}$ in SHAORN effluent $(0.03-0.16 \mathrm{mg} / \mathrm{L} ; \sim 8.2)$ were both under the inhibition threshold of anammox bacteria according to Egli et al. (2001) and Strous et al. (1999).

AOB and NOB are commonly present in ANAMMOX reactors (Kindaichi et al. 2012; Li et al. 2009; Liu et al. 2017; Park et al. 2010). Relative abundance of total AOB was low (0.04-0.36\%; Fig. 5), less than the $1.78 \%$ value reported by Liu et al. (2017). AOB groups in the present study were diverse and variable, including $N$. europaea, $N$. ureae and $N$. oligotropha, whereas previous studies found $N$. europaea to be the predominant AOB (Liu et al. 2017; Pereira et al. 2017). Genus Nitrospira, the predominant $\mathrm{NOB}$, was detected with dynamic changes in low relative abundances $(0-0.27 \%$, Fig. 5). Previous studies found Nitrospira to be the predominant NOB in ANAMMOX reactors, with relative abundance averaging 3.8\% (Kindaichi et al. 2012; Li et al. 2009; Liu et al. 2017; Park et al. 2010) - a considerably higher value than that in the present study.

In conclusion, we explored the microbial community dynamics in an ANAMMOX reactor from startup, increasing nitrogen load and stable performance for piggery wastewater treatment, which filled the gap among microbial community composition/anammox bacteria, running parameters and bioreactor performance. Microbial community composition and functional taxa played important roles in nitrogen removal efficiency. Influent ammonia, influent nitrite and effluent nitrate drove the dynamics of microbial community greatly, and some undefined factors, might also influence this dynamics, needed further study. Anammox 
bacteria could be enriched or eliminated depending on their ecological niches formed or not. Nitrite inhibition values to anammox groups were also elucidated, and this not only could explain the controversy of nitrite inhibition values but also revealed the optimal nitrogen loads to different anammox groups. These results would be useful to optimize running parameters for fast startup and high, stable efficiency of such bioreactors in practical application.

\section{Additional file}

\section{Additional file 1: Figure $\mathrm{S} 1$. Schematic diagram of the}

"UASB+SHARON+ANAMMOX" system for piggery wastewater treatment. (1) storage tank; (2) delivery pump; (3) gas meter; (4) UASB reactor; (5) effluent tank; (6) delivery pump; (7) warm water delivery pump; (8) SHARON reactor; (9) thermostat water bath; (10) air pump; (11) effluent tank; (12) suction pump; (13) delivery pump; (14) ANAMMOX reactor; (15) warm water delivery pump; (16) effluent tank. Figure S2. Heatmap plot illustrating relative percentages of major genera (clustering shown on vertical axis) within each sample (horizon-axis clustering) from ANAMMOX bioreactor. Numbers at bottom: times when activated sludge samples were obtained. Color intensities indicate relative abundances at genus level (legend at bottom). Figure S3. Four phyla were significantly correlated to Planctomycetes in the ANAMMOX bioreactor. Figure S4. A) Neighbor-joining tree of AOB OTUs based on 16S rRNA gene fragments. B) Relative abundance of these OTUs during the entire experimental period. Dotted line indicated day 229 when effluent from SHARON was used as influent. Bootstrap values (>50\%) shown on branch nodes are based on 1000 trials. Bar: evolutionary distance 0.01 .

\section{Abbreviations}

UASB: Upflow Anaerobic Sludge Blanket; SHARON: Single reactor system for High activity Ammonium Removal Over Nitrite; ANAMMOX: anaerobic ammonium oxidation; HRT: hydraulic retention time; COD: chemical oxygen demand; DO: dissolved oxygen; VS: volatile solids; SS: suspended solids; QIIME: Quantitative Insights Into Microbial Ecology; OTU: operational taxonomic units; PCoA: principle coordinates analysis; RDA: redundancy analysis; VPA: variation partitioning analysis; $\mathrm{NJ}$ : neighbor-joining.

\section{Authors' contributions}

QH performed the experiments assisted by WLD. QH contributed to analyze the data as well as results and wrote the manuscript. ZPL, LLM and YL conceived this study and constructed the bioreactors. ZPL supervised all the experiments and revised the manuscript. All authors read and approved the final manuscript.

\section{Author details}

${ }^{1}$ State Key Laboratory of Microbial Resources, Institute of Microbiology, Chinese Academy of Sciences, No. 1 West Beichen Road, Chaoyang District, Beijing 100101, People's Republic of China. ${ }^{2}$ University of Chinese Academy of Sciences, Beijing 100049, People's Republic of China.

\section{Acknowledgements}

The authors are grateful to Dr. S. Anderson for English editing of the manuscript.

\section{Competing interests}

The authors declare that they have no competing interests.

\section{Availability of data and materials}

Not applicable.
Consent for publication

Not applicable.

Ethics approval and consent to participate

Not applicable.

\section{Funding}

This study was supported by grants from the National Science and Technology Support Program of China (No. 2013BAD21B02-04) and National Natural Science Foundation of China (No. 31500103) and Program of Chinese Academy of Scineces (KFZD-SW-309). The authors are grateful to Dr. S. Anderson for English editing of the manuscript.

\section{Publisher's Note}

Springer Nature remains neutral with regard to jurisdictional claims in published maps and institutional affiliations.

Received: 20 August 2018 Accepted: 24 September 2018

Published online: 01 October 2018

\section{References}

Ali M, Chai LY, Tang CJ, Zheng P, Min XB, Yang ZH, Xiong L, Song YX (2013) The increasing interest of ANAMMOX research in China: bacteria, process development, and application. Biomed Res Int. https://doi. org/10.1155/2013/134914

Bernet N, Delgenes N, Moletta R (1996) Denitrification by anaerobic sludge in piggery wastewater. Environ Technol 17(3):293-300. https://doi. org/10.1080/09593331708616387

Bernet N, Delgenes N, Akunna JC, Delgenes JP, Moletta R (2000) Combined anaerobic-aerobic SBR for the treatment of piggery wastewater. Water Res 34(2):611-619. https://doi.org/10.1016/S0043-1354(99)00170-0

Boiran B, Couton Y, Germon JC (1996) Nitrification and denitrification of liquid lagoon piggery waste in a biofilm. Bioresour Technol 55(1):63-77. https:// doi.org/10.1016/0960-8524(95)00142-5

Caporaso JG, Kuczynski J, Stombaugh J, Bittinger K, Bushman FD, Costello EK, Fierer N, Pena AG, Goodrich JK, Gordon Jl, Huttley GA, Kelley ST, Knights $D$, Koenig JE, Ley RE, Lozupone CA, McDonald D, Muegge BD, Pirrung M, Reeder J, Sevinsky JR, Tumbaugh PJ, Walters WA, Widmann J, Yatsunenko T, Zaneveld J, Knight R (2010) QIIME allows analysis of high-throughput community sequencing data. Nat Methods 7:335-336. https://doi. org/10.1038/nmeth.f303

Casadesús J, D'Ari R (2002) Memory in bacteria and phage. BioEssays 24(6):512-518. https://doi.org/10.1002/bies.10102

Chen L, Liu F, Jia F, Hu YJ, Lai C, Li X, Luo P, Xiao RL, Li Y, Wu JS (2017) Anaerobic ammonium oxidation in sediments of surface flow constructed wetlands treating swine wastewater. Appl Microbiol Biotechnol 101:1301-1311. https://doi.org/10.1007/s00253-016-7957-y

Cho S, Takahashi Y, Fujii N, Yamada Y, Satoh H, Okabe S (2010) Nitrogen removal performance and microbial community analysis of an anaerobic up-flow granular bed anammox reactor. Chemosphere 78(9):1129-1135. https:// doi.org/10.1016/j.chemosphere.2009.12.034

Costa MC, Carvalho L, Leal CD, Dias MF, Martins KL, Garcia GB, Mancuelo ID, Hipolito T, Conell EF, Okada D, Etchebehere C, Chernicharo CA, Araujo JC (2014) Impact of inocula and operating conditions on the microbial community structure of two anammox reactors. Environ Technol 35(14):18111822. https://doi.org/10.1080/09593330.2014.883432

Date Y, Isaka K, Ikuta H, Sumino T, Kaneko N, Yoshie S, Tsuneda S, Inamori Y (2009) Microbial diversity of anammox bacteria enriched from different types of seed sludge in an anaerobic continuous-feeding cultivation reactor. J Biosci Bioeng 107(3):281-286

Dosta J, Vila J, Sancho I, Basset N, Grifoll M, Mata-Álvarez J (2015) Two-step partial nitritation/anammox process in granulation reactors: start-up operation and microbial characterization. J Environ Manage 164:196-205. https://doi.org/10.1016/j.jenvman.2015.08.23

Du WL, Huang Q, Miao LL, Liu Y, Liu ZP (2016) Association of running manner with bacterial community dynamics in a partial short-term nitrifying bioreactor for treatment of piggery wastewater with high ammonia content. AMB Express 6(1):76. https://doi.org/10.1186/s13568-016-0245-5 
Edgar RC, Robert C (2013) UPARSE: highly accurate OTU sequences from microbial amplicon reads. Nat Methods 10:996-998. https://doi. org/10.1038/nmeth.2604

Edgar RC, Haas BJ, Clemente JC, Quince C, Knight R (2011) UCHIME improves sensitivity and speed of chimera detection. Bioinformatics 27(16):21942200. https://doi.org/10.1093/bioinformatics/btr381

Egli K, Fanger U, Alvarez PJJ, Siegrist H, van der Meer JR, Zehnder AJB (2001) Enrichment and characterization of an anammox bacterium from a rotating biological contactor treating ammonium-rich leachate. Arch Microbiol 175(3):198-207. https://doi.org/10.1007/s002030100255

Fernández I, Dosta J, Fajardo C, Campos JL, Mosquera-Corral A, Mendez $R$ (2012) Short- and long-term effects of ammonium and nitrite on the Anammox process. J Environ Manage 95:170-174. https://doi. org/10.1016/j.jenvman.2010.10.044

Finlay BJ, Maberly SC, Cooper II (1997) Microbial diversity and ecosystem functioin. Oikos 80(2):209-213. https://doi.org/10.2307/3546587

Gauch J, Hugh G (1973) A quantitative evaluation of the Bray-Curtis ordination. Ecology 54(4):829-836. https://doi.org/10.2307/1935677

Hashimoto AG (1983) Thermophilic and mesophilic anaerobic fermentation of swine manure. Agric Wastes 6(3):175-191. https://doi.org/10.1016/01414607(83)90085-9

Hwang IS, Min KS, Choi E, Yun Z (2005) Nitrogen removal from piggery waste using the combined SHARON and ANAMMOX process. Water Sci Technol 52 (10-11):487-494

Isaka K, Sumino T, Tsuneda S (2007) High nitrogen removal performance at moderately low temperature utilizing anaerobic ammonium oxidation reactions. J Biosci Bioeng 103(5):486-490. https://doi.org/10.1263/ jbb.103.486

Jetten MSM, Wagner M, Fuerst J, Van Loosdrecht MCM, Kuenen G, Strous M (2001) Microbiology and application of the anaerobic ammonium oxidation ('anammox') process. Curr Opin Biotechnol 12(3):283-288. https:// doi.org/10.1016/S0958-1669(00)00211-1

Jin RC, Yang GF, Yu JJ, Zheng P (2012) The inhibition of the Anammox process: a review. J Chem Eng 197(15):67-79. https://doi.org/10.1016/j. cej.2012.05.014

Kimura Y, Isaka K, Kazama F, Sumino T (2010) Effects of nitrite inhibition on anaerobic ammonium oxidation. Appl Microbiol Biotechnol 86(1):359365. https://doi.org/10.1007/s00253-009-2359-z

Kindaichi T, Yuri S, Ozaki N, Ohashi A (2012) Ecophysiological role and function of uncultured Chloroflexi in an anammox reactor. Water Sci Technol 66(12):2556-2561. https://doi.org/10.2166/wst.2012.479

Kinnunen M, Dechesne A, Proctor C, Hammes F, Johnson D, Quintela-Baluja M, Graham D, Daffonchio D, Fodelianakis S, Hahn N, Boon N, Smets BF (2016) A conceptual framework for invasion in microbial communities. ISME J 10:2773-2775. https://doi.org/10.1038/ismej.2016.75

Krümmel A, Harms H (1982) Effect of organic matter on growth and cell yield of ammonia-oxidizing bacteria. Arch Microbiol 133(1):50-54

Lawson CE, Wu S, Bhattacharjee AS, Hamilton JJ, McMahon KD, Goel R, Noguera DR (2017) Metabolic network analysis reveals microbial community interactions in anammox granules. Nat Commun. 8:15416-15423. https://doi.org/10.1038/ncomms15416

Li XR, Du B, Fu HX, Wang RF, Shi JH, Wang Y, Jetten MS, Quan ZX (2009) The bacterial diversity in an anaerobic ammonium-oxidizing (anammox) reactor community. Syst Appl Microbiol 32(4):278-289. https://doi. org/10.1016/.jsyapm.2009.03.002

Li X, Sun S, Badgley BD, Sung S, Zhang H, He Z (2016) Nitrogen removal by granular nitritation-anammox in an upflow membrane-aerated biofilm reactor. Water Res 94:23-31. https://doi.org/10.1016/j.watres.2016.02.031

Liu W, Yang D, Chen W, Gu X (2017) High-throughput sequencing-based microbial characterization of size fractionated biomass in an anoxic anammox reactor for low-strength wastewater at low temperatures. Bioresour Technol 231:45-52. https://doi.org/10.1016/j.biort ech.2017.01.050

Ni SQ, Zhang J (2013) Anaerobic ammonium oxidation: from laboratory to full-scale application. Biomed Res Int 2013:469360

Park H, Rosenthal A, Jezek R, Ramalingam K, Fillos J, Chandran K (2010) Impact of inocula and growth mode on the molecular microbial ecology of anaerobic ammonia oxidation (anammox) bioreactor communities. Water Res 44(17):5005-5013. https://doi.org/10.1016/j.watres.2010.07.022
Pereira AD, Cabezas A, Etchebehere C, Chernicharo CA, Araújo JC (2017) Microbial communities in anammox reactors: a review. Environ Technol Rev 6(1):74-93. https://doi.org/10.1080/21622515.2017.1304457

Strous M, Heijnen JJ, Kuenen JG, Jetten MSM (1998) The sequencing batch reactor as a powerful tool for the study of slowly growing anaerobic ammonium-oxidizing microorganisms. Appl Microbiol Biotechnol 50(5):589-596. https://doi.org/10.1007/s002530051340

Strous M, Fuerst JA, Kramer EH, Logemann S, Muyzer G, van de Pas-Schoonen KT, Webb R, Kuenen JG, Jetten MS (1999) Missing lithotroph identified as new Planctomycete. Nature 400:446-449. https://doi.org/10.1038/22749

Strous M, Pelletier E, Mangenot S, Rattei T, Lehner A, Taylor MW, Horn M, Daims H, Bartol-Mavel D, Wincker P, Barbe V, Fonknechten N, Vallenet D, Segurens B, Schenowitz-Truong C, Médigue C, Collingro A, Snel B, Dutilh BE, Op den Camp HJM, van der Drift C, Cirpus I, van de Pas-Schoonen KT, Harhangi HR, van Niftrik L, Schmid M, Keltjens J, van de Vossenberg J, Kartal B, Meier H, Frishman D, Huynen MA, Mewes HW, Weissenbach J, Jetten MSM, Wagner M, Le Paslier D (2006) Deciphering the evolution and metabolism of an anammox bacterium from a community genome. Nature 440:790-794. https://doi.org/10.1038/nature04647

Sun W, Xu MY, Wu WM, Guo J, Xia CY, Sun GP, Wang AJ (2014) Molecular diversity and distribution of anammox community in sediments of the Dongjiang River, a drinking water source of Hong Kong. J Appl Microbiol 116(2):464-476. https://doi.org/10.1111/jam.12367

Suto R, Ishimoto C, Chikyu M, Aihara Y, Matsumoto T, Uenishi H, Yasuda T, Fukumoto Y, Waki M (2017) Anammox biofilm in activated sludge swine wastewater treatment plants. Chemosphere 167:300-307. https://doi. org/10.1016/j.chemosphere.2016.09.121

Tamura K, Stecher G, Peterson D, Filipski A, Kumar S (2013) MEGA6: molecular evolutionary genetics analysis version 6.0. Mol Biol Evol 30(12):27252729. https://doi.org/10.1093/molbev/mst197

Tang CJ, Zheng P, Mahmood Q, Chen JW (2010) Effect of substrate concentration on stability of Anammox biofilm reactors. J Central South Univ Technol. 17(1):79-84. https://doi.org/10.1007/s11771-010-0014-6

Tang CJ, Zheng P, Chen TT, Zhang JQ, Mahmood Q, Ding S, Chen XG, Chen JW, Wu DT (2011) Performance of high loaded ANAMMOX UASB reactors containing granular sludge. Water Res 45(1):135-144. https://doi. org/10.1016/j.watres.2010.08.018

Tong L, Li P, Wang Y, Zhu K (2009) Analysis of veterinary antibiotic residues in swine wastwater and environmental water samples using optimized SPE-LC/MS/MS. Chemosphere 74(8):1090-1097. https://doi.org/10.1016/j. chemosphere.2008.10.051

Trigo C, Campos JL, Garrido JM, Mendez R (2006) Start-up of the Anammox process in a membrane bioreactor. J Biotechnol 126(4):475-487. https:// doi.org/10.1016/j.jbiotec.2006.05.008

van de Graaf AA, Mulder A, de Bruijn P, Jetten MS, Robertson LA, Kuenen JG (1995) Anaerobic oxidation of ammonium is a biologically mediated process. Appl Environ Microbiol 61(4):1246-1251

Van Hulle SWH, Vandeweyer HJP, Meesschaert BD, Vanrolleghem PA, Dejans P, Dumoulin A (2010) Engineering aspects and practical application of autotrophic nitrogen removal from nitrogen rich streams. J Chem Eng. 162(1):1-20. https://doi.org/10.1016/j.cej.2010.05.037

van Niftrik L, Geerts WJ, van Donselaar EG, Humbel BM, Yakushevska A, Verkleij AJ, Jetten MS, Strous M (2008) Combined structural and chemical analysis of the anammoxosome: a membrane-bounded intracytoplasmic compartment in anammox bacteria. J Struct Biol 161(3):401-410. https://doi. org/10.1016/j.jsb.2007.05.005

Wang Q, Garrity GM, Tiedje JM, Cole JR (2007) Naive Bayesian classifier for rapid assignment of rRNA sequences into the new bacterial taxonomy. Appl Environ Microbiol 73(16):5261-5267. https://doi.org/10.1128/AEM.00062 $-07$

Wang T, Zhang H, Yang F, Li Y, Zhang G (2013) Start-up and long-term operation of the Anammox process in a fixed bed reactor (FBR) filled with novel non-woven ring carriers. Chemosphere 91(5):669-675. https://doi. org/10.1016/j.chemosphere.2013.01.026

Wang B, Peng Y, Guo Y, Zhao M, Wang S (2016) Illumina MiSeq sequencing reveals the key microorganisms involved in partial nitritation followed by simultaneous sludge fermentation, denitrification and anammox process. Bioresour Technol 207:118-125. https://doi.org/10.1016/j.biort ech.2016.01.072 
Wolf DM, Fontaine-Bodin L, Bischofs I, Price G (2010) Memory in microbes: quantifying history-dependent behavior in a bacterium. PLOS ONE 3(2):e1700. https://doi.org/10.1371/journal.pone.0001700

Yamada T, Sekiguchi Y, Imachi H, Kamagata Y, Ohashi A, Harada H (2005) Diversity, localization, and physiological properties of filamentous microbes belonging to Chloroflexi subphylum I in mesophilic and thermophilic methanogenic sludge granules. Appl Environ Microbiol 71(11):74937503. https://doi.org/10.1128/AEM.71.11.7493-7503.2005

Yamamoto T, Takaki K, Koyama T (2008) Long-term stability of partial nitritation of swine wastewater digester liquor and its subsequent treatment by anammox. Bioresour Technol 99:6419-6425. https://doi.org/10.1016/j. biortech.2007.11.052

Zhang L, Zheng P, Hu A (2009) Effect of ferrous ion on the performance of an anammox reactor. Acta Sci Circum 29(8):1629-1634

Zhu L, Wang Z, Shu Q, Takala J, Hiltunen E, Feng P, Yuan Z (2013) Nutrient

removal and biodiesel production by integration of freshwater algae cultivation with piggery wastewater treatment. Water Res 47(13):4294-4302. https://doi.org/10.1016/j.watres.2013.05.004

\section{Submit your manuscript to a SpringerOpen ${ }^{\circ}$ journal and benefit from:}

- Convenient online submission

- Rigorous peer review

- Open access: articles freely available online

- High visibility within the field

- Retaining the copyright to your article

Submit your next manuscript at springeropen.com 